\title{
ASSESSMENT OF NURSES' COMPLIANCE WITH OXYTOCIN ADMINISTRATION PROTOCOL DURING LABOR AT DAMMIETA CITY
}

\author{
Amal Mohammed Gamal'; Seham Shehata Ibrahem²; Fatma Zaki Farahat³ Rania Rezk \\ Esmail Shady ${ }^{4}$ \\ Assistant Professor of Maternal and Newborn Health Nursing, Faculty of Nursing - Menoufia \\ University Egypt ${ }^{1}$. Assistant Professor of Maternal, Obstetrics and Gynecology Nursing, Faculty \\ of Nursing - Port Said University Egypt ${ }^{2}$. Lecturer of Maternal, Obstetrics and Gynecology \\ Nursing, Faculty of Nursing - Port Said University Egypt. ${ }^{3}$
}

\begin{abstract}
Background: Oxytocin is safe when used correctly. Complications usually follow improper doses or inadequate supervision .Oxytocin administration errors are a significant source of professional liability. Aim: Assess nurses' knowledge and practices toward compliance with oxytocin administration protocol during labor. Design: A cross sectional descriptive design was adopted. Setting: The study was conducted at Obstetrics and Gynecology department in four hospitals named: Altakhasosy Hospital, Al Azhar Hospital, General Damietta Hospital and Kafr Saad Hospital in Damietta city. Subjects: A total of fifty five nurses. Tools: Three tools were used for data collection: 1-Structured Self -administered questionnaire, 2- an observational check list and 3- assessment sheet. Results: About two third of the nurses had poor knowledge about use of oxytocin administration protocol, and there was a statistically significant relation between average total knowledge score of studied nurses and their working shift, years of experiencing in nurses. The majority of them had unsatisfactory Practice level, and there was no statistically significant relation between the average total practice score of studied nurses and their demographic characteristics, their work characteristics, only between average total practice score and years of experiencing in midwifery. Conclusion: nurses had poor knowledge about use of oxytocin, and most of them had unsatisfactory practice. Recommendations: periodic inservices training programs on oxytocin administration to improve nurses knowledge and practice is needed, further studies to identify factors responsible for the low quality of nursing care during childbirth to any complication also needed .
\end{abstract}

Key words: Nurses' compliance; oxytocin administration protocol; labor 


\section{INTRODUCTION}

Childbirth is a most wonderful, pleasurable event to the mother but at the same time it is also a life-threatening event to her. Hence, ensuring safe childbirth is the responsibility of a maternity nurse by promoting and preserving the health of the mother and fetus from conception to childbirth (Sathiya, 2015). Labor is considered a life changing event for most women and families all over the world. Also, labor is associated with great risks and in severe cases disability and even death for mother or child (WHO, 2018).

Induction of labour is the stimulation of uterine contractions during pregnancy before labor begins on its own to achieve a vaginal birth. It is most often performed by administering oxytocin or prostaglandins to the pregnant woman or by manually rupturing the amniotic membranes (WHO, 2011). Labour induction and augmentation should only be carried out by highly qualified health workers in facilities with access to emergency obstetric care due to increased risks of complications accompanying these procedures (Deepak, Mirzabagi, Koski, \& Tripathi, 2013).

Oxytocin is the most commonly used induction agent worldwide and is utilize to stimulate or augment labor in 50\%of all births in the United States. Furthermore, one of the leading causes of obstetrical liability claims involves the administration of Oxytocic (Boston, Hall, \& Fraser, 2009; Hidalgo-Lopezosa, Hidalgo-Maestre \& Rodríguez-Borrego, 2016). It was designated as high-alert medication in 2007by the institute for safe medical practice. High-alert medications are recognized as those medications that require special considerations and precautions before and during administration which increased risk of causing significant patient harm when used in error (Krening, 2012; Clark, Simpson, Knox, \& Garite, 2009; Williams, 2007).

Oxytocin is a serious medicine that needs close monitoring to avoid consequences as fetal respiratory distress caused by severe uterine contraction and uterine rupture. . In addition, it needs close monitoring to evaluate progress of labor and to detect signs of failure of induction if they occur early to prevent adverse outcomes (Clark, Rice Simpson, Knox \& Garite, 2011).

Compliance defined as the act or method of obliging to a need, demand, proposal, or programme or with coercion. Hence, if the nurse becomes able to acknowledgement and compliance guidelines of medications administration, all the previous oxytocin complications 
and side effects can be controlled or completely disappeared. So, understanding of safe administration and management of the drug is critical (Tyreman, 2012).

Nurses have a major role in compliance to guidelines of medications administrations to women during labour, especially with high alert medication as (Oxytocic) which includes nurse role before, during, and after administration of oxytocin. Nurse role before oxytocin administration as checking five rights of medication, assess maternal vital signs, uterine contraction as well as fetal heart rate. While nurse role during oxytocin administration as monitoring maternal, fetal condition, intake and output chart, and manage any complication arise, and nurse role after oxytocin administration as documentation and reporting (Freeman , Nageotte, 2007; WHO, 2012).

\section{Significance of this study}

Safe childbirth is the responsibility of the maternity nurse by promoting and preserving the health of the mother and foetus. There are various drugs that are used during the pregnancy cycle. A group of drugs called "oxytocics" are commonly administered to expectants mothers for the management of abortions, post-dated pregnancy, labour and puerperium. Nurses at the bedside of the laboring women make oxytocin titration decision based on their nursing assessment. Misuse of labor inducing medication such as oxytocin has been identified as contributing to maternal and neonatal mortality. Use of labor-inducing medication by insufficiently trained cadres of healthcare workers is prevalent. The stakes are high, with unregulated usage of such medication resulting in severe consequences for mother and child (McKinney, , James, Murray, Nelson,\& Ashwill, 2017; Safieh, 2014). So nurses must be up to date in their knowledge and be careful to learn all practical procedures following guidelines related to medication administration to save maternal \&fetal life (Williams, 2007;WHO,2002).

\section{AIM OF STUDY}

This study aimed at assess the nurses' knowledge and practices toward compliance with oxytocin administration protocol during labor. 


\section{SUBJECT AND METHOD}

\section{Research Design:}

Cross sectional Descriptive design was utilized in this study.

\section{Setting:}

The study was conducted at obstetric and gynecological department in four hospitals in Damietta governorate namely: Al-Azhar University Hospital, General Damietta Hospital, Altakhasosy Hospital, and KafrSaad Hospital.

\section{Study sample:}

There are two samples where determined:

First sample: A total of 55 nurse, they are a total of nurses study, who was provide nursing care for hospitalized woman with induction by oxytocin.

Second Sample: A total of (165) women who attending the previously mentioned selected obstetric and gynecological department and fulfilling the following inclusion criteria .

\section{Inclusion criteria:}

1. Assigned to normal vaginal delivery.

2. Women at reproductive age from (20-35) years old.

3. Gestational age above 37 week.

4. Induced by oxytocin.

\section{Exclusion criteria:}

- A pregnant woman diagnosed with severe cardiovascular disease

- Women who delivered previously by cesarean section.

-Any condition where vaginal delivery inadvisable.

Sample type: Convenience sample. 
Sampling procedure: Purposive sampling was used to select the subjects for the study.

\section{Sample Size:}

Second Sample: A sample of (165) women who attended the previously mentioned study settings and fulfilling the inclusion criteria were enrolled in this study during the period of data collection (8 months).

The sample was determined by using the way of $25 \%$ from average number women who was induced by oxytocin drug during labor in previous mentioned setting.

Total numbers=2384 rate of hospital administration at 2017

Average number $=596$

Sample size $=\mathbf{1 4 9}$

The calculated sample is 149 women. Due to expected non-participating rate (10\%), the final sample size is 165 laboring women. At least three women for each nurse .

\section{Tools of data collection:}

Data were collected using three tools devised specifically for the study these tools include the following. Tool (I): Self-administered questionnaire for nurses

It was designed by research investigator after reviewing related literatures, it was written in Arabic language and composed of two parts containing open and closed ended questions to assess the following:-

- Part (I): Socio-demographic characteristic data of studied nurses:

It was contained questions about nurses" name, age, works of place, marital status, level of education, years of experience and previous training in labor and delivery unit.

Part (II): Nurses knowledge regarding oxytocin administration such as: definition, administrations rout and, complication, nursing intervention for oxytocin administration mother and etc....

\section{Knowledge scoring system:}

A score of each question was given as follows:

-Correct answer scored $=(1) \quad-$ Incorrect answer scored $=(0)$ 
As well as nurses' total knowledge score was classified as the following:

- Total nurses' knowledge considered UN satisfied (poor) when the total score is $<50 \%$.

- Total nurses' knowledge considered fair when the total score is $50 \%$ to $<75 \%$.

- Total nurses' knowledge considered satisfied (good) when the total score is $\geq 75 \%$.

\section{Tool (II): Observational checklist for nurses}

- It was used to assess the nurses' performance which includes data related to practical skills provided by nurses for mothers with oxytocin administration. That included admission care, vital signs measurement, fetal heart rate count...etc.

It contained 33 items grouped in 3 main sections as follows:

- Nurses role before oxytocin administration( $\mathrm{N}=9)$

- Nurses role during oxytocin administration $(\mathrm{N}=16)$

- Nurses role after oxytocin administration $(\mathrm{N}=8)$

Scoring system: Nurses performance were scored: Done compliance or practice in objective (satisfied) scored (2),incompletely done compliance or practice in objective ( unsatisfied ) scored (1), and Not done compliance or practice in objective scored (0). The total score ranged between $(33-66)$.

As well as nurses' total practice score was calculated as following:

- The total practical skills was considered satisfied if the percentage of total practices scored $\geq 60$ $\%$

- The total practical skills will be considered UN satisfied if the percentage of total practices scored $<60 \%$.

\section{Tool III: Assessment sheet for women:}

This tool was developed by the researcher to collect data related to:

- Sociodemographic characteristics such as: age, address, level of education, occupation, marital status and housing condition.

- Medical history such as: diabetes, hypertension, heart disease, kidney disease, anemia and. 
- Obstetric history such as: gravid, parity, number of abortion, previous method of delivery, any complications during previous delivery, problems related to present pregnancy, duration of pregnancy, and method of present delivery.

Tools Validity: The tools were developed by the researcher based on review of related literature and similar tools. They were exposed to face and content-validated by a panel of six university experts in obstetrics and gynecology from nursing discipline.

Content reliability: Tools were tested for reliability using Cronbach's alpha test which the nurses' knowledge about oxytocin administration was $=0.726$, and an observational check list was $=0.872$. The tools were proved to be reliable with Cronbach's alpha test.

\section{Pilot Study:}

Before embarking on the actual study, a pilot study was conducted on $10 \%$ of the study subjects which represent 17 women, and 6 nurses who were excluded from the study sample. The purposes of the pilot study were to test the applicability and clarity and feasibility of the study tools and it served to estimate the time needed to complete the tools. It also helped to find out any obstacles and problems that might interfere with data collection process. Based on findings of the pilot study, no certain modifications on the tools were done.

\section{Field work:}

The data was collected through two days per week to each hospital which means six days per week. Collection of data covered a period of eight months" from the first of May 2018 to the end of December 2018". The data collection process was conducted by observation of nurses during their administration of oxytocin using observational checklist (tool II).Each nurse was observed 3 times: during morning shift (8am to2am) and the evening shift (2am to8am).There are no differences found in their action between observation one, two and three. Tool III was completed at the same time from the women and hospital record. Tool I was distributed to the nurses during the break time to evaluate their knowledge about oxytocin after completing (tool II\& Tool III). After completion, the researcher ensures that all statements included in the tools were completed. Then, nurses were thanked for their cooperation. 


\section{Administrative design}

Before starting any step in the study, an official letter was issued from the Dean of the faculty of nursing to the director of each previously mentioned study setting requesting his/her cooperation and permission to conduct the study in obstetric and gynecological department, after explaining the aim of the study.

\section{Ethical considerations:}

1. An official permission was taken from directors of the previously mentioned study settings to carry out the study.

2. An oral consent was obtained from the nurses and women after explaining the aim of the study.

3. The studied nurses were assured that the information obtained was confidential and used only for the purpose of the study and anonymity is guaranteed.

4. The studied subjects were informed that their participation is voluntary and they had the right to with draw from the study at any time. This study has not any harmful for nurses or mothers and does not touch religious cultural and ethical issues.

\section{RESULTS:}

Table (1): Reveals that studied nurses' age ranges between 20-50 years with a mean age \pm SD of 33.11 6.18 years, two third of them (60.0\%) their age ranges between 30 to less than 40 years old. Looking to their level of education, it is found that, two- third of the nurses $(65.5 \%)$ had diploma level of education. It is also observed that the high majority of them (87.3\%) were married and more than three quarter of the nurses (80.0\%) live in Rural. As regard to family income, $52.7 \%$ of the studied nurses had enough income monthly. Only $23.6 \%$ of them had training courses, about half of them $(53.8 \%)$ had two courses, and $46.4 \%$ had the last course from one year. This entire course (100\%) was provided by ministry of health.

Table (2): show that $81.8 \%$ of the studied nurses had not correct answer about definition of oxytocin $.74 .5 \%$ hadn't correct answer for the relation between oxytocin\& bonding. Looking to the best method to give the oxytocin, and the labour where it used, the most of nurses $92.7 \%$ had correct answer. 
Table (3): Describes that the majority of nurses (90.9\%) had correct answer for indication of oxytocin, $63.6 \%$ hadn't correct answer for mothers' contraindications of using oxytocin, while $41.8 \%$ hadn't correct answer about fetus' contraindications of using oxytocin. $85.5 \%$ of studied nurses had correct answer about nurse role at occurrence of side effects, but had not correct answer about side effects and complications to the newborn.

Table (4): show that the highest percentage of the studied nurse (65.5\%) had low level of knowledge about use of oxytocin, third of them (30.9\%) had fair level of knowledge while only $3.6 \%$ of them had high level of knowledge about use of oxytocin.

Table (5): represents that all of studied nurses (100.0\%) were satisfied checking woman's name and 60.0\% not satisfied in Comparing name of oxytocin with woman's sheet 3 times to ensure correct name. In regarding to assess FHR more than three quarter of studied nurses $78.2 \%$ didn't do it.

Table (6): Illustrates nurses' role after administration of oxytocin . More than three quarter of them (83.6\%) Satisfied marked Signature in women sheet, and the half (50.9\%) not satisfied record Observations notified to the physician. It's observed that the high majority of studied nurses (96.4\%) didn't record women Intake \& output.

Table (7): show that $94.5 \%$ of studied nurses had unsatisfactory practice after women induction with oxytocin, while $25.5 \%$ of them had satisfactory practice before women induction with oxytocin with Mean \pm SD $11.92 \pm 2.67$. Regarding to Total score practice $87.3 \%$ of them had Unsatisfactory Practice Level with Mean \pm SD $35.31 \pm 11.0$.

Table (8): Shows that there is statistically significant relationship between average total knowledge score and sociodemographic characteristics of the studied nurses in the areas of educational level, age group, and Marital status whereas $p$-value $\leq 0.05$, and there was a statistically significant relation between the average total knowledge score of studied nurses and their years of experiencing in nurses whereas (P 0.001) and number of working hours. Its elicits that there is no statistically significant relation between the average total knowledge score of studied nurses and years of experiencing in midwifery, attending training courses. 
Table (1): Demographic and profile of the studied nurses $(n=55)$

\begin{tabular}{|c|c|c|c|}
\hline \multirow[t]{2}{*}{ Personal characteristics } & \multicolumn{2}{|c|}{ Studied nurses $(n=55)$} & \multirow[t]{2}{*}{ Test /p value } \\
\hline & No & $\%$ & \\
\hline $\begin{array}{l}\text { Age (years) : } \\
20-<30 \\
30-<40 \\
40-50\end{array}$ & $\begin{array}{r}15 \\
33 \\
7\end{array}$ & $\begin{array}{l}27.3 \\
60.0 \\
12.7\end{array}$ & $\begin{array}{l}\text { Range: } 22.0-47.0 \\
\text { Mean } \\
\text { SD }=33.11 \pm 6.18 \\
\text { Median }=34.0\end{array}$ \\
\hline $\begin{array}{l}\text { Education : } \\
\text { Diploma } \\
\text { Technical } \\
\text { Bachelor }\end{array}$ & $\begin{array}{c}36 \\
12 \\
7\end{array}$ & $\begin{array}{l}65.5 \\
21.8 \\
12.7\end{array}$ & \\
\hline $\begin{array}{l}\text { Marital status : } \\
\text { Single } \\
\text { Married } \\
\text { Divorced } \\
\text { Widow }\end{array}$ & $\begin{array}{c}3 \\
48 \\
2 \\
2\end{array}$ & $\begin{array}{l}5.5 \\
87.3 \\
3.6 \\
3.6\end{array}$ & \\
\hline $\begin{array}{l}\text { Residence : } \\
\text { Urban } \\
\text { Rural }\end{array}$ & $\begin{array}{l}11 \\
44\end{array}$ & $\begin{array}{l}20.0 \\
80.0\end{array}$ & \\
\hline $\begin{array}{l}\text { Family income : } \\
\text { Not enough } \\
\text { Enough }\end{array}$ & & $\begin{array}{l}47.3 \\
52.7\end{array}$ & \\
\hline $\begin{array}{l}\text { Attending training } \\
\text { No } \\
\text { Yes }\end{array}$ & $\begin{array}{l}42 \\
13\end{array}$ & $\begin{array}{l}76.4 \\
23.6\end{array}$ & \\
\hline $\begin{array}{l}\text { Number of training courses }(\mathrm{n}=13) \\
\text { One } \\
\text { Two } \\
\text { Three }\end{array}$ & $\begin{array}{c}(\mathrm{n}=13) \\
5 \\
7 \\
1\end{array}$ & $\begin{array}{c}38.5 \\
53.8 \\
7.7\end{array}$ & \\
\hline $\begin{array}{l}\text { Duration since last training }(\mathrm{n}=13) \\
<\text { one year } \\
1-<2 \\
2-5 \text { years }\end{array}$ & $\begin{array}{l}6 \\
2 \\
5\end{array}$ & $\begin{array}{c}46.4 \\
15.4 \\
38.5\end{array}$ & \\
\hline
\end{tabular}


Table (2): Distribution of the study nurses according to their general knowledge about oxytocin administration. $(\mathrm{n}=55)$

\begin{tabular}{|c|c|c|c|c|c|}
\hline \multirow{3}{*}{ Questions } & \multicolumn{5}{|c|}{ Studied nurses $(\mathrm{n}=55)$} \\
\hline & \multicolumn{2}{|c|}{$\begin{array}{l}\text { Not } \\
\text { correct }\end{array}$} & \multicolumn{2}{|c|}{ Correct } & $\begin{array}{l}\text { Average } \\
\text { score }\end{array}$ \\
\hline & No & $\%$ & No & $\%$ & \multirow{2}{*}{$\begin{array}{l}\text { Range: } 3.0- \\
12.0\end{array}$} \\
\hline Nature of oxytocin & 45 & 81.8 & 10 & 18.2 & \\
\hline the source of oxytocin & 36 & 65.5 & 19 & 34.5 & \multirow{4}{*}{$\begin{array}{l}\text { Mean } \pm \\
\mathrm{SD}=6.34 \\
\pm 2.44 \\
\text { Median }=6.0\end{array}$} \\
\hline Reasons for administration & 22 & 40.0 & 33 & 60.0 & \\
\hline Oxytocin is used in which stage of labor & 39 & 70.5 & 16 & 29.1 & \\
\hline $\begin{array}{l}\text { Best way of Oxytocin administration during } \\
\text { labor }\end{array}$ & 4 & 7.3 & 51 & 92.7 & \\
\hline $\begin{array}{l}\text { Type of labor in which Oxytocin are } \\
\text { administered }\end{array}$ & 4 & 7.3 & 51 & 92.7 & \\
\hline Effect of Oxytocin on uterine muscles & 18 & 32.7 & 37 & 67.3 & \\
\hline Factors affecting Oxytocin effectiveness & 18 & 32.7 & 37 & 67.3 & \\
\hline relation between oxytocin \& milk expression & 37 & 67.3 & 18 & 32.7 & \\
\hline What is this relation? & 39 & 70.9 & 16 & 29.1 & \\
\hline relation between oxytocin \& bonding & 38 & 69.1 & 17 & 30.9 & \\
\hline What is this relation? & 41 & 74.5 & 14 & 25.5 & \\
\hline $\begin{array}{l}\text { Warning signs be reported to the doctor during } \\
\text { oxytocin administration }\end{array}$ & 25 & 45.5 & 30 & 54.5 & \\
\hline percentage of the nurses knowledge & & 0.9 & & & \\
\hline
\end{tabular}


Table (3): Nurses' knowledge about use of oxytocin use, side effects \& complications . ( n=55)

\begin{tabular}{|c|c|c|c|c|c|}
\hline \multirow{3}{*}{ Questions } & \multicolumn{5}{|c|}{ Studied nurses $(n=55)$} \\
\hline & \multicolumn{2}{|c|}{ Not correct } & \multicolumn{2}{|c|}{ Correct } & Average score \\
\hline & No & $\%$ & No & $\%$ & \multirow{4}{*}{$\begin{array}{l}\text { Range: } 0.0-3.0 \\
\text { Mean } \pm S D \\
=1.85 \pm 0.97 \\
\text { Median }=2.0\end{array}$} \\
\hline Indications of oxytocin & 5 & 9.1 & 60 & 90.9 & \\
\hline Mothers' contraindications of using oxytocin & 35 & 63.6 & 20 & 36.4 & \\
\hline Fetus' contraindications of using oxytocin & 23 & 41.8 & 32 & 58.2 & \\
\hline Available oxytocin dose in the unit & 0 & 0.0 & 55 & 100 & \\
\hline Hospital practice of using oxytocin & 10 & 18.2 & 45 & 81.8 & \\
\hline Side effects to the mothers & 39 & 70.9 & 16 & 29.1 & Range:0.0-7.0 \\
\hline Complications to the mothers & 10 & 18.2 & 45 & 81.8 & Mean \pm SD \\
\hline Side effects to the fetus & 19 & 34.5 & 36 & 65.5 & $=3.58 \pm 1.57$ \\
\hline Complications to the fetus & 37 & 67.3 & 18 & 32.7 & Median $=3.0$ \\
\hline Side effects and complications to the newborn & 47 & 85.5 & 8 & 14.5 & \\
\hline In what of labor, oxytocin is used? & 28 & 50.9 & 27 & 49.1 & \\
\hline Nurse role at occurrence of side effects & 8 & 14.5 & 47 & 85.5 & \\
\hline Meaning of oxytocin protocol & 8 & 14.5 & 47 & 85.5 & \\
\hline percentage of the nurses knowledge & 25.5 & & 74.5 & & \\
\hline
\end{tabular}

Table (4): summary of total nurses' knowledge score to compliance of oxytocin administration. ( $\mathrm{n}=55)$

\begin{tabular}{|l|l|l|l|}
\hline Level of knowledge & Values & No & \% \\
\hline Poor knowledge & $<50.0 \%$ & 36 & 65.5 \\
\hline Fair knowledge & $\begin{array}{l}50.0 \% \text { t0 } \\
75.0 \%\end{array}$ & 17 & 30.9 \\
\hline Good knowledge & $\geq 75.0 \%$ & 2 & 3.6 \\
\hline & Ranges of score & Mean \pm SD & Median \\
\cline { 2 - 4 } & $\mathbf{5 . 0}-\mathbf{2 1 . 0}$ & $\mathbf{1 1 . 7 8} \pm \mathbf{3 . 6 3}$ & $\mathbf{1 1 . 0}$ \\
\hline
\end{tabular}


Table (5): Distribution of the nurses' practice according to their Compliance before administration of oxytocin $(n=55)$

\begin{tabular}{|c|c|c|c|c|c|c|}
\hline \multirow{4}{*}{ Items } & \multicolumn{6}{|c|}{ Studied nurses $(n=55)$} \\
\hline & \multicolumn{4}{|c|}{ Done } & \multirow{2}{*}{\multicolumn{2}{|c|}{ Not done }} \\
\hline & \multicolumn{2}{|c|}{ Satisfied } & \multicolumn{2}{|c|}{ Not satisfied } & & \\
\hline & No & $\%$ & No & $\%$ & No & $\%$ \\
\hline $\begin{array}{l}\text { 1-Checking woman's name by asking her name or } \\
\text { checking rest band }\end{array}$ & 55 & 100.0 & 0 & 0.0 & 0 & 0.0 \\
\hline $\begin{array}{l}\text { 2-Comparing name of oxytocin with woman's sheet } \\
3 \text { times to ensure correct name }\end{array}$ & 16 & 29.1 & 33 & 60.0 & 6 & 10.9 \\
\hline $\begin{array}{l}\text { 3-Reviewing woman's sheet for correct date, time \& } \\
\text { dose of oxytocin }\end{array}$ & 26 & 47.3 & 25 & 45.5 & 4 & 7.3 \\
\hline $\begin{array}{l}\text { 4-Making sure that gestational age is } 39 \text { weeks or } \\
\text { more }\end{array}$ & 4 & 7.3 & 11 & 20.0 & 40 & 72.7 \\
\hline $\begin{array}{l}\text { 5- Reviewing woman's sheet to ensure clarity of } \\
\text { physician's order }\end{array}$ & 27 & 49.1 & 25 & 45.5 & 3 & 5.5 \\
\hline 6-Assessing woman's vital signs \& blood pressure & 38 & 69.1 & 17 & 30.7 & 0 & 0.0 \\
\hline 7-Assessing fetal heart rate & 4 & 7.3 & 8 & 14.5 & 43 & 78.2 \\
\hline $\begin{array}{l}\text { 8-Performing complete pelvic examination by } \\
\text { physician or the midwives }\end{array}$ & 52 & 94.5 & 3 & 5.5 & 0 & 0.0 \\
\hline 9-Obtaining informed consent & 41 & 74.5 & 8 & 14.5 & 6 & 10.9 \\
\hline
\end{tabular}


Table (6): Distribution of the nurses practice according to their Compliance after administration of oxytocin $(n=55)$

\begin{tabular}{|c|c|c|c|c|c|c|}
\hline \multirow{4}{*}{ Items } & \multicolumn{6}{|c|}{ Studied nurses $(n=55)$} \\
\hline & \multicolumn{4}{|c|}{ Done } & \multirow{2}{*}{\multicolumn{2}{|c|}{ Not done }} \\
\hline & \multicolumn{2}{|c|}{ Satisfied } & \multicolumn{2}{|c|}{ Not satisfied } & & \\
\hline & No & $\%$ & No & $\%$ & No & $\%$ \\
\hline $\begin{array}{l}\text { Documentation of the following data about } \\
\text { oxytocin infusion in woman's sheet }\end{array}$ & & & & & & \\
\hline $\begin{array}{l}\text { 26-Dose of oxytocin as well as amount \& type } \\
\text { of solution }\end{array}$ & 40 & 72.7 & 15 & 27.3 & 0 & 0.0 \\
\hline $\begin{array}{l}\text { 27-Initial oxytocin rate, increasing or decreasing } \\
\text { rate, discontinuation or restarting }\end{array}$ & 12 & 21.8 & 23 & 41.8 & 20 & 36.4 \\
\hline $\begin{array}{l}\text { 28-FHR or its changes as well as duration, } \\
\text { interval \& intensity of contraction every } 30 \text { min } \\
\& \text { on changing dose }\end{array}$ & 2 & 3.6 & 5 & 9.1 & 48 & 87.2 \\
\hline 29-Maternal vital signs and blood pressure & 32 & 58.2 & 21 & 38.2 & 2 & 3.6 \\
\hline 30- Vaginal exams \& their findings & 6 & 10.9 & 8 & 14.5 & 41 & 74.5 \\
\hline 31-Intake \& output & 1 & 1.8 & 1 & 1.8 & 53 & 96.4 \\
\hline 32-Observations notified to the physician & 1 & 38.2 & 28 & 50.9 & 6 & 10.9 \\
\hline 33-Signature & 46 & 83.6 & 6 & 10.9 & 3 & 5.5 \\
\hline
\end{tabular}

Table (7): summary of total nurses practice score to compliance of oxytocin administration $(n=55)$

\begin{tabular}{|l|l|l|l|l|l|l|l|}
\hline \multirow{2}{*}{ Practice Level } & \multicolumn{2}{|l|}{$\begin{array}{l}\text { Unsatisfactory } \\
(<75 \%)\end{array}$} & \multicolumn{2}{l|}{$\begin{array}{l}\text { Satisfactory } \\
(\geq 75 \%)\end{array}$} & \multicolumn{3}{l|}{ Average score } \\
\cline { 2 - 8 } & No & $\%$ & No & $\%$ & $\begin{array}{l}\text { Max } \\
\text { score }\end{array}$ & $\begin{array}{l}\text { Min } \\
\text { Max }\end{array}$ & Mean \pm SD \\
\hline Before & 41 & 74.5 & 14 & 25.5 & 18 & $7-18$ & $11.92 \pm 2.67$ \\
\hline During & 45 & 81.8 & 10 & 18.2 & 32 & $7-32$ & $15.62 \pm 6.91$ \\
\hline After & 52 & 94.5 & 3 & 5.5 & 16 & $3-16$ & $7.76 \pm 2.64$ \\
\hline Total practice & 48 & 87.3 & 7 & 12.7 & 66 & $21-64$ & $35.31 \pm 11.0$ \\
& & & & & & & \\
\hline
\end{tabular}


Table (8): Relationship between average total knowledge score and sociodemographic, work characteristics, of the studied nurses $(\mathrm{n}=55)$

\begin{tabular}{|c|c|c|c|}
\hline Items & No $(n=55)$ & \begin{tabular}{|l|} 
Total score \\
Mean + SD
\end{tabular} & $\begin{array}{l}\text { Significance } \\
\text { test }\end{array}$ \\
\hline $\begin{array}{l}\text { Age (years) } \\
20-<30 \\
30-<40 \\
40-50\end{array}$ & $\begin{array}{l}15 \\
33 \\
7\end{array}$ & $\begin{array}{l}14.60 \pm 2.64 \\
11.09 \pm 3.46 \\
09.00 \pm 2.71\end{array}$ & $\begin{array}{l}F=9.375 \\
P<0.001\end{array}$ \\
\hline $\begin{array}{l}\text { Education } \\
\text { Diploma } \\
\text { Technical } \\
\text { Bachelor }\end{array}$ & $\begin{array}{l}36 \\
12 \\
7\end{array}$ & $\begin{array}{l}10.67 \pm 2.52 \\
14.91 \pm 2.87 \\
12.14 \pm 6.20\end{array}$ & $\begin{array}{l}F=7.737 \\
P 0.001\end{array}$ \\
\hline $\begin{array}{l}\text { Marital status } \\
\text { Single } \\
\text { Married } \\
\text { Divorced } \\
\text { Widow }\end{array}$ & $\begin{array}{l}3 \\
48 \\
2 \\
2\end{array}$ & $\begin{array}{l}15.67 \pm 1.53 \\
11.63 \pm 3.67 \\
12.00 \pm 4.24 \\
09.50 \pm 0.70\end{array}$ & $\begin{array}{l}F=1.475 \\
P 0.232\end{array}$ \\
\hline $\begin{array}{l}\text { Residence } \\
\text { Urban } \\
\text { Rural }\end{array}$ & $\begin{array}{l}11 \\
44\end{array}$ & $\begin{array}{l}11.73 \pm 3.92 \\
11.80 \pm 3.61\end{array}$ & $\begin{array}{l}\mathrm{t}=0.055 \\
\mathrm{P} 0.956\end{array}$ \\
\hline $\begin{array}{l}\text { Family income } \\
\text { Not enough } \\
\text { Enough }\end{array}$ & $\begin{array}{l}26 \\
29\end{array}$ & $\begin{array}{l}10.08 \pm 2.77 \\
12.41 \pm 4.21\end{array}$ & $\begin{array}{l}\mathrm{t}=1.373 \\
\mathrm{P} 0.176\end{array}$ \\
\hline $\begin{array}{l}\begin{array}{l}\text { Years of experiencing in } \\
\text { nursing }\end{array} \\
<5 \\
5-<15 \\
15-25\end{array}$ & $\begin{array}{l}8 \\
21 \\
26\end{array}$ & $\begin{array}{l}14.38 \pm 2.92 \\
12.95 \pm 4.03 \\
10.04 \pm 2.58\end{array}$ & $\begin{array}{l}F=7.614, \\
P 0.001\end{array}$ \\
\hline $\begin{array}{l}\begin{array}{l}\text { Years of } \\
\text { midwifery }\end{array} \\
\text { experiencing in } \\
5-<15 \\
5-25\end{array}$ & $\begin{array}{l}19 \\
24 \\
12\end{array}$ & $\begin{array}{l}12.42 \pm 3.24 \\
12.38 \pm 3.89 \\
09.58 \pm 3.03\end{array}$ & $\begin{array}{l}F=3.019 \\
P 0.058\end{array}$ \\
\hline $\begin{array}{l}\text { Number of working hours } \\
6 \\
8 \\
12\end{array}$ & $\begin{array}{l}16 \\
25 \\
14\end{array}$ & $\begin{array}{l}10.06 \pm 3.04 \\
11.56 \pm 3.91 \\
14.14 \pm 2.51\end{array}$ & $\begin{array}{l}F=5.608 \\
P 0.006\end{array}$ \\
\hline
\end{tabular}




\section{DISCUSSION:}

Childbirth is important and a life changing event so, the care given to women may affect both mother and her baby physically and emotionally in the short and longer term (Karlström, Nystedt, \& Hildingsson, 2015).

Induction of labour is the process of artificially stimulating the uterus to start labour. To avoid potential risks associated with the induction the woman and her baby need to be monitored closely to identify and manage any complication (WHO, 2014). Oxytocin is the most commonly used induction agent worldwide and is utilize to stimulate or augment labor in 50\%of all births in the United States. Furthermore, one of the leading causes of obstetrical liability claims involves the administration of Oxytocic (Baston Hall, Fraser, 2009; Bugg, Siddiqui, Thornton , 2013).

Oxytocin is one of the most frequently used drugs in obstetrics, but it is also the drug accompanied with the most preventable adverse events in childbirth. All midwives bear a huge obligation when they administering drugs, since these may affect not only on the mother but also on the fetus during delivery and on the newborn. As an active member in the care group, midwife plays an essential role in detecting the changes of oxytocin use. Nurses particularly the midwife, should be very careful when administering the oxytocin and follow it up with full monitoring as, it can be harmful to the life of both the mother and fetus (Mosbys, 2015).

Therefore, this study was conducted to evaluate nurses' compliance with oxytocin administration protocol during labour. This aim was achieved through assess nurses' knowledge and practices regarding use of oxytocin during labor.

The finding of the present study denoted that the highest percentage of the studied nurse, two third $(65.5 \%)$ had low level of knowledge about use of oxytocin, while only $3.6 \%$ of them had high level of knowledge about use of oxytocin. So, we can understand from the findings that majority of the staff nurses had below average level of knowledge.

This study was carried on 55 nurses. Two third of them (60.0\%) their age ranges between 30 to less than 40 years old, about two thirds of them had secondary school of nursing, less than half $(45.5 \%)$ of them their experience in obstetric ward in ranges between (5-14) years, less than half 
$(45.5 \%)$ of them working for 8 hours, and more than two-third $(70.9 \%)$ of nurses provided care to patient in range between 1-9for each nurse, and The high majority of them (89.1\%) didn't have another work. only $23.6 \%$ of them had training courses about labor. This explains why the majority of them had inadequate knowledge.

This finding goes in line with Shrestha, (2017) who reported that majority of respondents $37 \%$ belongs to $31-35$ years of age group, minority of the respondents $18 \%$ were in the age group of above 35 years of age group, the distribution includes majority of staff nurses $53 \%$ of them were married, and minority $47 \%$ of them were un-married. With regard to educational qualification, $83 \%$ of the staff nurses were GNM, total years of experience maximum $39 \%$ of staff nurses had above 6 years' experience, and 63.3\% had Inadequate knowledge $(<50 \%)$ knowledge regarding maternal and neonatal outcome of induction of labour.

This is congruent with Shiny, (2017) study in Chennai about assessment of the knowledge and practice on use of oxytocin among nurses working in selected hospitals who showed that the majority of the staff nurses were in age group of 21 -30 years. This is also matching with the study of Thamer (2014) about assessment of nurses' knowledge regarding oxytocin administration during labor at maternity hospitals in Al-Kut City who indicated that $62.9 \%$ of nurses had no training in the administration of oxytocin during labor and $52.9 \%$ of them had more than 5 years of experience.

In other hand; the current finding is not in harmony with Durodola, Kuti, Orji, \& Ogunniyi (2005) who study titled had "Rate of increase in oxytocin dose on the outcome of labor induction". Their study shows that head nurses and doctors had good knowledge about oxytocic administration. The differences between finding of the present study and Durodola may be due to the fact that the present study subjects are stuff nurses, while in Durodola study are medical staff and professional nurses.

Regarding knowledge about the relation between oxytocin and milk expression and the relation between oxytocin and bonding, about two third of nurses hadn't correct answer. This lack of knowledge may be due to this knowledge are not practiced. These results were in the same direction with Roma, Al-Battawi, \& Zaki, (2014) who demonstrated that the vast majority $(87.5 \%$ and $88.33 \%)$ gave incorrect answers or didn't know the relation between oxytocin and 
milk expression and the relation between oxytocin and bonding respectively. The similarity between Roma and present study may be due to the majority of subjects in two studies didn't receive any training programs about oxytocin drug and didn't had any training programs.

World Health Organization, (2013) reported that the nurses who

offer care to women during labor must be have a base of knowledge that

guide them to accomplish their nursing practice. Unfortunately, the

findings of the present study revealed that, $60.0 \%$ of studied nurses had Poor knowledge about general knowledge for oxytocin administration related to the source of oxytocin, which stage of labor use and best way of oxytocin administration during labour (table 4). This may be due to lack of continuous educational programs. The current study findings are in contrast with Roma, Al-Battawi, \& Zaki (2014).

The current study revealed that $65.5 \%$ of nurses had inadequate knowledge, third of them (30.9\%) had fair level of knowledge while only $3.6 \%$ of them had high level of knowledge about use of oxytocin during labour. These results were supported by Ahla, Fatihah\&Norziyana (2015) who conducted a study to assess the knowledge of nurses' midwives regarding nursing care of a women receiving oxytocin drug during labour in El Ribat who stated that, 32.3\% of staff nurses had sufficient pretest knowledge. The same results were also observed by Haleena\&Prathap (2013) who evaluates the knowledge and practice of oxytocin induction and quality of delivery care among staff nurses working in maternity ward. The results of the research concluded that, $61.6 \%$ of nurses had insufficient knowledge. This study is in agreement with other study done by Mohamed, Desoky, Metwally(2019) that studied the effect of educational Program on improving nursing knowledge and Practice regarding administration of oxytocin during labour the study concluded that $36.3 \%$ of nurses mentioned correct answer in pretest related to the action of oxytocin. Regarding the effect of oxytocin on labor, $73.3 \%$ of nurses had correct answer. As for maternal factors that influence augmentation of labor with oxytocin, only $20.0 \%$ of nurses had correct answer.

The present study showed that $94.5 \%$ of studied nurses had unsatisfactory practice after women induction with oxytocin, while $25.5 \%$ of them had satisfactory practice before women 
induction with oxytocin with Mean \pm SD $11.92 \pm 2.67$. Regarding to total score of practice $87.3 \%$ of them had unsatisfactory Practice level with Mean \pm SD $35.31 \pm 11.0$. This is in agreement with Shiny (2017) who reported that $72.9 \%$ of the staff nurses had insufficient knowledge and $66.2 \%$ of them had bad practice regarding administration of oxytocin during delivery. This corresponds well with the study of Ali, \&Ameer (2012) about knowledge and practice on oxytocin administration techniques among staff nurses working in maternity hospitals in Al-Hillah City who emphasized that more than half of the staff nurses had insufficient knowledge and poor practice. This finding on the same line with the findings of Shiny (2017) who shows that majority (45\%) of the staff nurses had poor practice, $32.5 \%$ of the staff nurses had moderate practice and $22.5 \%$ of the staff nurses had good practice on use of oxytocin.

Regarding relationship between average total knowledge score and sociodemographic characteristics of the studied nurses, and work characteristics of the studied nurses. The present study Shows that there is statistically significant relationship between average total knowledge score and sociodemographic characteristics of the studied nurses in the areas of educational level, age group, and Marital status whereas p-value $\leq 0.05$, there was a statistically significant relation between the average total knowledge score of studied nurses and their years of experiencing in nurses whereas ( $\mathrm{P}$ 0.001)and number of working hours, but there is no statistically significant relation between the average total knowledge score of studied nurses and years of experiencing in midwifery, attending training courses.

This study is in agreement with Shiny (2017) who reported that there was a statistically significant association between the level of knowledge on use of oxytocin among staff nurses with the age and religion at $\mathrm{p}<0.001$, income per month at $\mathrm{p}<0.01$, the educational status, total working experience at $\mathrm{p}<0.05$ and working experience in maternity unit at $\mathrm{p}<0.001$, in-service education on use of oxytocin at $\mathrm{p}<0.001$, level of significance, and there was no statistically significant association between level of knowledge on use of oxytocin with the maximum working experience in maternity unit $\&$ current area of working.

The finding of present study is not in congruence with the finding of Shrestha (2017) that explains that the all demographic variable such as age, religion, marital status, educational 
qualification, total years experiences, monthly income, shows that there is no statistical association with pretest level of knowledge at $5 \%$ level of significance.

\section{CONCLUSION:}

\section{Based on the findings of the present study, it can be concluded that:}

The highest percentage, two third of the studied nurse $(65.5 \%)$ had poor knowledge about use of oxytocin, while only (3.6\%) of them had good knowledge, and 30.9\% had fair knowledge about use of oxytocin. Regarding to total score of practice $87.3 \%$ of them had unsatisfactory Practice Level with Mean \pm SD 35.31 \pm 11.0.

\section{RECOMMENDATIONS:}

\section{Based on the results of the present study, the following recommendations were suggested:}

* Designing and implementing an educational training program to nurses about high alert medications (as Oxytocin) that used in labour unit.

* Every health institution must have written protocol on safe oxytocin administration.

* Conducting periodic in-services training program for midwifery nurses who are handling cytotoxic drugs to improve knowledge and safe handling measures and reduce the harmful effects of these drugs among nurses is considered of great importance.

\section{Further studies:}

-Further studies are recommended to investigate the effect of educational training program on nurses' knowledge and practice.

-Further studies are recommended in other settings to Investigate barriers against nurses' compliance with drug administration guidelines.

\section{REFERENCES:}

Ahla, Fatihah\&Norziyana (2015): Assessment of nurse's midwives knowledge regarding nursing care of a woman who receiving oxytocin drug during labor, Ribat University, Faculty Graduate Studies \& Scientific Research.

Ali, H \&Ameer, A (2012): A cross sectional study of knowledge and practice on use of oxytocin. 
Boston, H., Hall J., Fraser, J. (2009). Labor. Midwifery Essentials. 3rded Elsevier, 94-7.

Bugg GJ, Siddiqui F, Thornton JG. (2013). Oxytocin versus no treatment or delayed treatment for slow progress in the first stage of spontaneous labour. The Cochrane database of systematic reviews . (6):Cd007123.

Chalmers, B. (2017). Family-Centered Perinatal Care. Cambridge University Press .

Clark SL, Simpson KR, Knox GE and Garite TJ (2009): Oxytocin: New perspectives on an old drug. Am J ObstetGinecol; 200:35-6.

Clark S, Rice Simpson K, Knox G and Garite T (2011): Oxytocin: new perspectives on an old drug. Am J Obstetric Gynecology; 35:2.

Deepak, N. N., Mirzabagi, E., Koski, A., \& Tripathi, V. (2013) . Knowledge, attitudes, and practices related to uterotonic drugs during childbirth in Karnataka, India: a qualitative research study. PloS one, www.plosone.org; e62801, 8 (4).

Durodola, A., Kuti, O., Orji, E. O., \& Ogunniyi, S. O. (2005) . Rate of increase in oxytocin dose on the outcome of labor induction. International Journal of Gynecology \& Obstetrics, 90(2), 107-111.

Freeman, R., Nageotte, M,A. (2007). Protocol for use of oxytocin .American Journal of obstetrics \& Gynecology.5 (197)445-6 .

Haleena\&Prathap, V (2013): Retrospective study of assess the knowledge and practice regarding oxytocin induction and quality of delivery care.

Hidalgo-Lopezosa P, Hidalgo-Maestre M and Rodríguez-Borrego MA (2016): Labor stimulation with oxytocin: effects on obstetrical and neonatal outcomes Rev. Latino-Am. Enfermagem; 24:e2744.

Karlström, A., Nystedt, A., \& Hildingsson, I. (2015) . The meaning of a very positive birth experience: focus groups discussions with women. BMC pregnancy and childbirth, 15(1), 251. 
Krening., Cynthia, F. MS, RNC-OB, C-EFM . (2012) . Rehling-Anthony, Kimberly MSN, RN, WHNP, IBCLC, C-EFM; Garko, Candace MSN, RNC-OB, C-EFM . Journal of perinatal \& neonatal nursing: January/March- 26 (1) -15-24.

McKinney, E. S., James, S. R., Murray, S. S., Nelson, K., \& Ashwill, J. (2017). Maternalchild nursing-e-book. Elsevier Health Sciences.

Mohamed ,A ., Desoky, M., Metwally,H.(2019). Effect of educational program on improving nursing knowledge and practice regarding administration of oxytocin during labor . IOSR Journal of nursing and health science (IOSR-JNHS) . 8(5), PP 44-53 www.iosrjournals.org . DOI: 10.9790/1959-0805104453 .

Mosbys (2015): Nursing drug reference text book, 28th edition, published by Elsiver.

Osterman, M.J., Martin, J.A. (2014). Recent declines in induction of labor by gestational age. NCHS Data Brief ; 1 .

Roma, N., Al-Battawi, JN., \& Zaki, N. (2014) . Nurses' Compliance with oxytocic administration guidelines during labor . Alexandria Scientific nursing Journal, 16(2), 55-72

Sarathi , S. (2015) .Complications of oxytocin in induction of labour. IOSR Journal of nursing and health science (IOSR-JNHS) .4( 2 ), PP 29-32 www.iosrjournals.org, DOI: $\underline{10.9790 / 1959-04252932 .}$

Shiny, S. T. (2017) . Assessment of the knowledge and practice on use of oxytocin among nurses working in selected hospitals in Chennai (Doctoral dissertation, MA Chidambaram College of Nursing, Chennai).

Shrestha, R. (2017). The effectiveness of self instructional module on knowledge regarding maternal and neonatal outcome of induction of labour among staff nurses in selected hospital, Bangalore, India. Journal of advanced academic research, 4(2), 79-91.

Thamer, H. (2014). Assessment of Nurses' Knowledge regarding oxytocin administration during Labor at maternity hospitals in Al-Kut City . Iraqi National Journal of Nursing Specialties, 1(27), 1-10. 
Tyreman, C. (2012). How to avoid drug errors. Available at URL: http://www.nursingtimes.net/how-to-avoid-drug-errors/5018923.article Retrieved on: 14 April.

Williams, D. J. P.(2007). Medication errors . Journal -royal College of physicians of Edinburgeh, 37(4), 343.

WHO (2012). Recommendations for Induction of labor. Available at URL: http//www.who.int/reproductivehealth/publications/maternal_perinatal_health/9789241501156/e n index.html retrieved on: 10 October.

WHO (May 2014) . recommendation on high starting and increment dosage regimen of oxytocin for labour augmentation. The WHO Reproductive Health Library; Geneva: World Health Organization.

WHO,(2002). Essential Antenatal, Perinatal and Postpartum Care Training modules .Regional office for Europe .

Available at :http://www.euro. /assets/pdf.file/0013/131521/E79235.pdf Retrieved on: 2 $\underline{\text { March } 2013}$

World Health Organization, (2011) . BACKGROUND Recommendations for Induction of Labour .

World Health Organization, (2013) . Transforming and scaling up health professionals' education and training: World Health Organization guidelines 2013.

WorldHealthOrganizatiion,(2018):WHO recommendations:intrapartum care for a positive childbirth experience Available at: http://www.who.int/reproductivehealth/ publications/intrapartum-care-guidelines. 


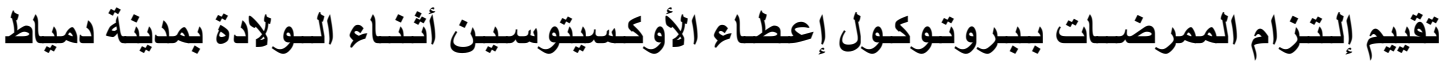

\section{أمل محمد جمال1، سهام شحاتة (براهيج2, فاطمة زكي فرحات, رنيا رزق إسماعيل شادي4}

أستاذ مساعد تمريض صحة الأم وحديثى الو لادة بكلية التمريض - جامعة المنوفية1. أستاذ مساعد تمريض الأمومة والنساء

و التوليد بكلية التمريض - جامعة بورسعيد². مدرس تمريض الأمومة و النساء و التوليد بكلية التمريض - جامعة بورسعيد3

\section{الخـلاصـة}

الأوكسيتوسين آمن عند استخدامه بشكل صحيح. عادة ماتتتج المضاعفات من جرعات غير مناسبة أو مر اقبة غير كافية. أخطاء إعطاء الأوكسيتوسين هي مصدر مهم للمسؤولية المهنية. هدف البحث: هدفت هذه الدراسة الوصفية إلى تقييم مستوى معرفة وممارسات الممرضات تجاه الامتثال لبروتوكول إعطاء الأوكسيتوسين أثناء الولادة. وقد أجريت هذه الدراسة بقسم أمر اض الإه النساء و الو لادة في أربعة مستشفيات هي: مستشفى التخصصي ، ومستشفى الأزهر ، ومستشفى دمياط العام ، ومستشفى كفر سعد بمدينة دمياط. وشملت عينة البحث خمسة وخمسون (55) ممرضة عاملة في المستشفيات المذكورة سابقاً في الدراسة. . طرق وادوات البحث: تم استخدام ثلاث أدوات لجمع البيانات: 1- استمارة استبيان 2- استمارة الملاحظة لاداء التمريض، 3- استمارة تقييم. النتائج: كثفت أن: حوالي ثلثي الممرضات يفتقرن إلى المعرفة حول استخدام بروتوكول إعطاء الأوكسيتوسين ، وكانت هناك علاقة ذات دلالة إحصائية بين منوسط درجات المعرفة الإجمالية للممرضات الخاضعات للار اسة وفترة عملهن ، وسنوات الخبرة. كان لدى الغالبية منهم مستوى ممارسة غير مرضٍ ، ولم تكن هناك علاقة ذات دلالة إحصائية بين متوسط درجات الممارسة الإجمالية للممرضات المدروسات وخصائصهن الديموغر افية ، وخصائص عملهن ، فقط بين متوسط مجموع درجات الممارسة وسنو ات الخبرة في التوليد. الاستنتاجات: كان لدى الممرضات معرفة ضعيفة حول استخدام الأوكسيتوسين ، ومعظمهم مارسو ا ممارسات غير مرضية. التوصيات: هناك حاجة إلى بر امج تدريب دورية أثناء الخدمة حول إعطاء الأوكسيتوسين لتحسين معرفة الممرضات وممارساتها ، ودراسات إضافية لتحديد العوامل المسؤولة عن الجودة المنخفضة للر عاية التمريضية أثناء الو لادة.

الكلمات المرشدة :الولادة ، تحفيز الولادة ، الأوكسيتوسين ، دور الممرضة 